\title{
WILLINGNESS TO ACCEPT OF ADOPTING SUSTAINABLE TERUBOK FISHERIES IN SARAWAK BY USING CONTINGENT VALUATION METHOD
}

\author{
Nur Syahmina Abdul Ghanie* \\ Universiti Malaysia Sarawak \\ Dayang Affizzah Awang Marikan \\ Universiti Malaysia Sarawak \\ Nor Afiza Abu Bakar \\ Universiti Malaysia Sarawak
}

\begin{abstract}
Sarawak is well known with its Terubok which is scientifically known as Tropical shad Tenualosa. In Sarawak, there are two types of Tenualosa that found namely Tenualosa toli and Tenualosa macura. However, due to the overexploitation and heavy fishing of terubok, the total catch landing has been declining. Therefore, the main objective of this study is to investigate the potential of establishing sustainable terubok fisheries in order to sustain the population of terubok and livelihoods of Sarawak fisherman. This study is conducted in the core terubok area which are Batang Lupar, Batang Lassa and Batang Sadong. This study employed Contingent Valuation Method (CVM) to estimate the willingness to accept (WTA) of the fisherman to conserve terubok. This study found out that the bidding amount, race which is Malay and Melanau, size of household and the fisherman experience may affect the WTA of the fishers. Besides, RM 301.08 is the average amount of compensation that will be given to the Terubok fisherman in order to conserve the Terubok populations. This study also recommends that the Terubok fisherman should be more educated and educational training for the fisherman should be provided so that they may realize the importance of conserving Terubok.
\end{abstract}

Keywords: Willingness to Accept, Terubok, Contingent Valuation Method

Received:23 April 2020

Accepted: 14 September 2020

\section{INTRODUCTION}

Agricultural sector which includes crops, livestock and fisheries is one of the most important sectors in Malaysia as it contributes to the national income. In 2018, the agriculture sector had contributed RM 99.5 billion to Gross Domestic Product (GDP) of Malaysia which is equivalent to 7.3 percent of GDP and 12.5 percent of the GDP comes from fisheries sector (Department of Statistics Malaysia, 2019). Tropical shad or locally known as ikan Terubok are commercially and culturally important estuarine fishes in many Asian country including Malaysia and it has a high

\footnotetext{
- Corresponding author: Faculty of Economics and Business, Universiti Malaysia Sarawak, 94300, Kota Samarahan, Sarawak, Malaysia. Tel: +60146912747. Email: gsyahmina@gmail.com
} 
commercial value that contributes to the national economy (Rahim, Tumiran, Mohd, Esa, Ahmad \& Awang, 2014; Arjunaidi, Zakaria, Abdul, Shahreza, Mat Jaafar, Seah, Nur Asma, 2016). The Tropical shad family are consisting of five clupidae family which is known as Tenualosa ilisha, Tenualosa macura, Tenualosa revesii, Tenualosa thibaudaui and Tenualosa toli (Blaber, Milton, Chenery, \& Fry, 2003).

Different Tenualosa has their own habitat to live in. According to the Sarawak Inland Fisheries Department (2015), Tenualosa ilisha can only be found in the coastline of Bangladesh, Myanmar, Vietnam and India whereas Tenualosa revesii can be found at the Eastern Indian Ocean. Other than that, Tenualosa thibaudaui can be found at Mekong River in Cambodia, Laos, Thailand and Vietnam. Both Tenualosa macura and Tenualosa toli can only be found in the Sarawak River. Specifically, Tenualosa macura can be found at Sebuyau, Batang Sadong, Batang Saribas and Batang Lassa. As for Tenualosa toli, it can be found at the river estuary in the nortern coast of Borneo which is in Batang Lupar, Batang Saribas, Batang Lassa and Sungai Krian.

The terubok population had faced a major decline of due to heavy fishing and overexploitation since 1980's even in the core terubok areas (Rahim et al., 2014). Knowing the fact that the population had decline, the fisherman still fish for terubok as the fisherman can earned higher income be it season or non-season for terubok. This is because the fisherman can put a higher price when it is sold at the market since terubok is a highly demanded product for their tasty eggs as well as their mouthwatering meat. Grafton, Arnaron, Bjornal, Campbell, Campbell, Clark, and Weninger (2006) had stated six principal factors that may lead to the global decline of marine ecosystem which are inappropriate incentives, scarcity, poverty, inadequate knowledge, ineffective governance and low interaction among fishery sectors and other aspects of environment. Within decades, if there is no proper rules and regulations is implemented, many marine species are said to be extinct and might be an endangered species (Heal \& Schlenker, 2008). According to the study of Bakeri, Affizzah, Abdullah and Ashraf (2020), Terubok fish especially in Sarawak are difficult to obtain besides the limited number of Terubok found in the coastal area. In addition, the Terubok fish that is found in the market nowadays are imported from India and Myanmar.

Figure 1 shows that the total landing for both Tenualosa macura and Tenualosa toli are increasing from year to year. Close Season Program which is implemented by the Enforcement and Licensing Unit (ELU) in 2007 until 2012 can be said as a successful program as the total landing for both of the Tenualosa species is at a stable amount of catch. However, the total landing of the species had increased drastically after 2012. This indicates that the Tenualosa species population is increasing after the Close Season Program being implemented which may led to a higher catch by the fishers. However, if the total landing of terubok keep on increasing from year to year, it is worrying that the number of terubok population will diminish and these species will be classified as an endangered species in the near future if there is no proper rules and regulation being enforced. 
Figure 1: Total Landing of Tenualosa Macura and Tenualosa Toli

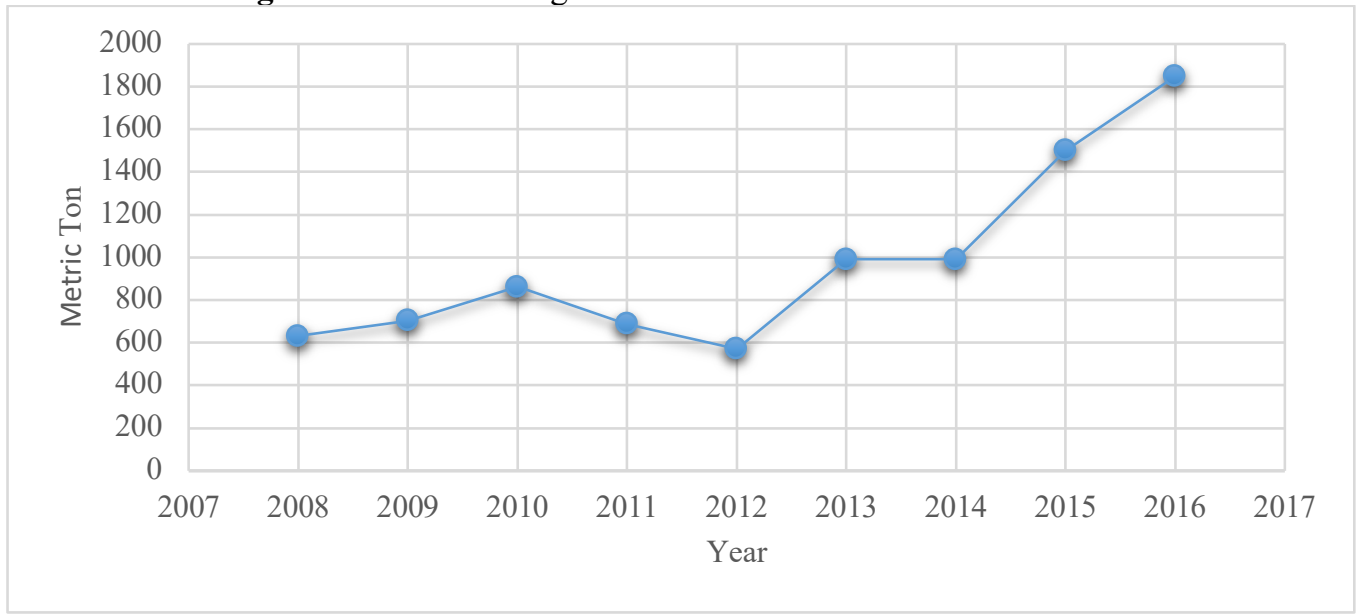

Source: Department of Fisheries Malaysia (2008-2016)

Looking into the livelihood of the fisherman, they are living in poverty where in other words it can be said that their earning is just enough for the day. In order to improve the socioeconomic level of the fisherman, the focus had been given by the Fisheries Development Authority of Malaysia (LKIM) to empower the social and economic welfare of the fisherman community as well as to develop the fisheries sector in Malaysia. However, being a fisherman is sort of like a tradition in the family and have to be continued by the next generation (Mohd, Chang, \& Sintoh, 1994). The fisherman also faces a major problem as the middleman had gain more profit than the fisherman itself (Raduan, Sharir \& Aziz, 2007). Therefore, it can be said that the middleman has the power to determine the price of the terubok in the market. Hence, it is very crucial for the government together with the Non-Governemnt Organization (NGO) to intervene into these issues in order to sustain and enhance the terubok fisherman livelihood and the ecosystem can be conserved.

Few researchers have addressed the issue that is related to the cycle of life, biology, history and ecology of the Tenualosa species in order to maintain and sustain the population of these species (Blaber, Milton, Pang, Vong, Ong, Nyigo \& Lubin, 1996). However, there are little information that was known about the fisherman's preferences on the compensation that will be given to them if they are prohibited to catch terubok for certain period. Therefore, an effective conservation strategies and management should be applied in order to sustain as well as to protect the Tenualosa family specifically toli and macura in Sarawak.

\subsection{Study Area}

This study is conducted in a few divisions in Sarawak which consist of Terubok fisherman. The core Terubok areas are selected as the study area as suggested by the Sarawak Inland Fisheries Centre. For that reason, this study will be carried out at Batang Lupar, Lingga in Sri Aman division, Batang Lassa, Daro in Mukah division and Batang Sadong, Ladong in Samarahan division. 
Figure 2: Core Terubok Areas in Sarawak

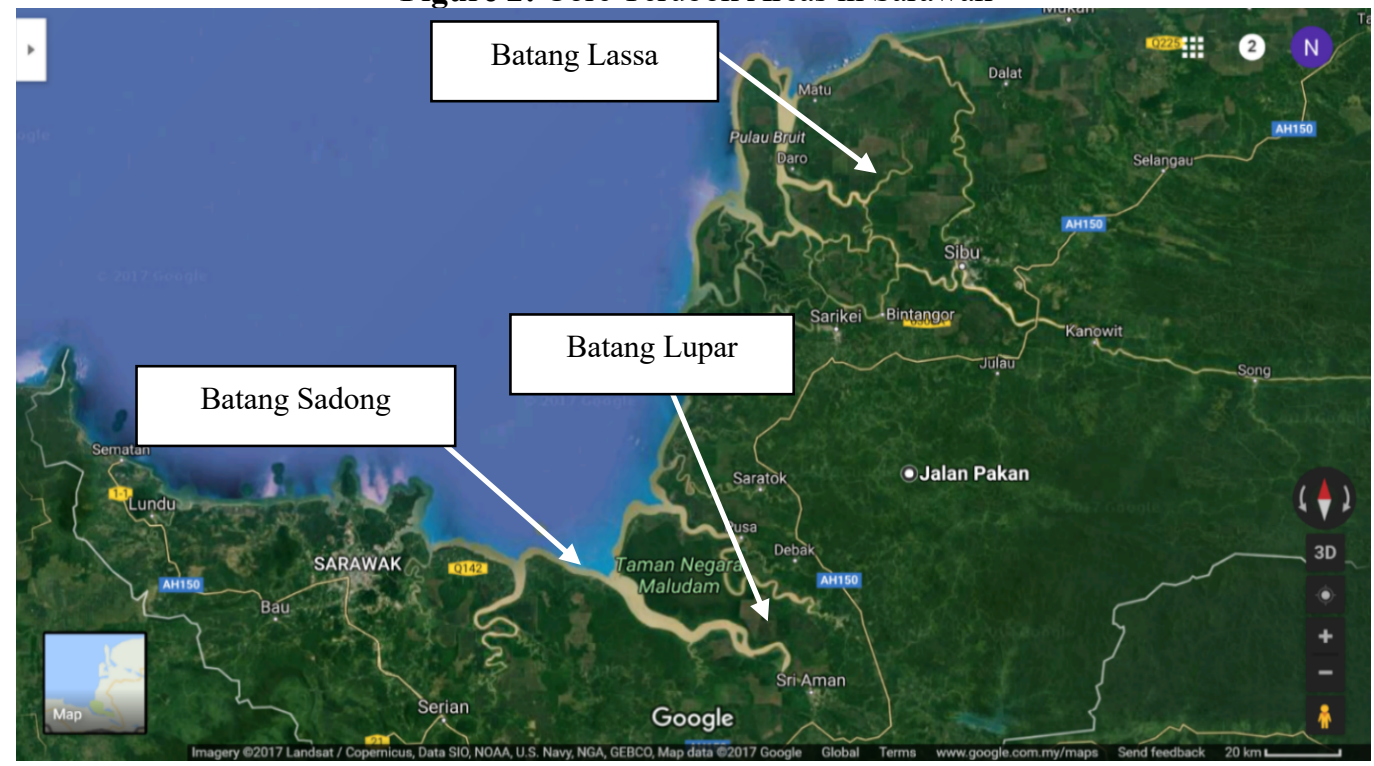

Source: Google Maps (2018)

The data for the Terubok fisherman is provided by the the Sarawak Inland Fisheries Centre and there are 250 respondents that has been interviewed which consist only the terubok fisherman at the core terubok areas. Based on the data given by the Sarawak Inland Fisheries Centre, the total population of the Teruok fisherman in Sarawak are 398 fishermen.

\section{METHODOLOGY}

\subsection{Research Methods}

This study employed stratified random sampling technique as the population is divided into subgroups which is called strata. Basically, the common criterion used to divide the strata are age, gender, origin and socioeconomic status. For the purpose of this study, the subgroup are divided by the profession which is the fisherman, the fisherman that is actively catching terubok, the location which is in the core terubok areas and the terubok fisherman that is monitored by the Sarawak Inland Fisheries. In order to estimate the Willingness to Accept (WTA), Contingent Valuation Method (CVM) are often used as the method to measure the welfare losses and gained (Brown \& Gregory, 1999). Since CVM is classified under Stated Preferences approach, therefore CVM is used to gain the information of their preferences by doing the hypothetical payment scenarios and this information is then used to produce the monetary values of people's WTA. WTA is define as the minimum amount of compensation that will be given to the respondents for the changes that might affect them (Haneman, 1991; Shogren \& Hayes, 1997). A recent study of Bakeri et al., (2020) adapting CVM in a study of tenualosa toli found out that the method is suitable to value the terubok fish in order to preserve them from extinction. 
There are several techniques that can be adapted by using Stated Preferences approach. One of the technique is bidding game. Bidding game offers several amount of bids with the final question is an open-ended question (Pearce \& Ozdemiroglu, 2002). By using this technique, the amount of bids will increase or decrease until the maximum results is achieved. The bidding game may reassure the respondents to consider their preferences carefully. However, this technique may lead to the risk of the respondents may be influenced by the starting amount of bids. According to Bateman, Carson, Day, Hanemann, Hanley, Heff and Sugden (2002) and Pearce and Ozdemiroglu (2002), the payment cards and dichotomous choice elicitation format are the most recommended elicitation technique. However, the payment card may come out with an unnecessary hypothetical bias. This is because, people get to decide on the value that is more than they actually accept. On top of that, the open-ended elicitation leads to a large non-response rates and expose to unrealistically large bids responses. This is because the respondent's may face some difficulties in revealing their true amount of WTA for the change that they are not familiar with (Pearce \& Ozdemiroglu, 2002). Besides, in this study, the fisherman with a low educational level will not be able to answer the question precisely if open ended format is implemented. Therefore, dichotomous choice elicitation format is employed to estimate the WTA of the terubok fisherman. On top of that, dichotomous choice may be incentive friendly and facilitate respondents' valuation task.

\subsection{Questionnaire Design}

The data collection is conducted by using questionnaire in order to obtain their WTA amount. The questionnaire was in Malay language as it is easier for the fisherman to understand it. During the survey, there are some issues when it comes to explaining to the respondents as some of them are illiterate. The enumerator has to explain to the respondents in a simple Sarawak Malay language in order to obtained the most appropriate and correct answer based on the situation given in the questionnaire. A total of 250 questionnaire were issued and only 200 questionnaires were valid for estimation after the data cleaning process. This study employed stratified sampling as the target respondents are only the terubok fisherman and areas of sampling are conducted at the core terubok areas.

In order to estimate the fisherman's WTA, the questionnaire will be divided into three sections. Section I will be on the attitudinal questions where the information collected is used to measure a particular attribute of a products or services. In short, it is a measure on how the consumer feels about something. In this case, the attitudinal questions are presented to the fisherman in order to identify their opinion on terubok.

In Section II, the contingent valuation questions will be presented. The fisherman will be given a scenario that explains the current situation of terubok. In the scenario given, it will also ask on the fisherman WTA amount with different amount of bids in different questionnaire. On top of that, the fisherman will also be asked on their maximum amount of WTA considering their income that they earn every month.

Lastly in Section III is the sociodemographic questions which is a common section in any survey. It is important to include this section as it is important to know the respondent's information to ensure that the study is reaching out for the exact target audience. 


\subsection{Logistic Regression Model}

Logistic regression is an analysis used to explain the relationship between one dependent variable which is dichotomous and one or more independent variable which the variable is nominal, ordinal, interval or ratio. The logit model is used in this study to analyze the willingness to accept of the fisherman. This type of regression model is easier to be applied compared to any other model plus it has the advantage to estimate the probability of the fisherman who are willing to accept or not the compensation given (Anning, Egyir, Kwadzo, \& Kuworm, 2012). The model specified the probability of the fisherman to agree or reject the bid that are presented to them. The Logit model is specified as below:

$$
\mathrm{p}=1 /\left(\left(1+e^{\wedge}(-\mathrm{z})\right)\right)
$$

Where $\mathrm{p}$ denotes the probability of yes or no; $\mathrm{Z}$ denotes Logit prediction of yes or no and $\mathrm{e}$ is the error term. The WTA estimation of this study was generalized and adopted from Bett, Bett, Kahi, and Peters (2009). The empirical model is specified as follows:

$\mathrm{WTA}=\beta 0+\beta 1$ Bidding $+\beta 1$ Melanau $+\beta 2$ Malay $+\beta 3 \mathrm{HH}+\beta 4 \mathrm{YEAR}+\beta 5 \mathrm{EDU}+\beta 6 \mathrm{INC}+\mathrm{e}$

Table 1: Definition and Measurement of Variables

\begin{tabular}{ll}
\hline \hline \multicolumn{1}{c}{ Variable } & \multicolumn{1}{c}{ Description } \\
\hline Bidding Amount (Bidding) & The bidding price offered to the respondents measured in RM \\
Race & The race of the respondents. The race used in the estimation is \\
& Melanau and Malay \\
Household Size (HH) & The number of people in the house \\
Fisherman's Experience (YEAR) & $\begin{array}{l}\text { The duration of respondents being terubok fisherman measured } \\
\text { in years }\end{array}$ \\
Education (EDU) & The level of education of the fisherman \\
Income (INC) & The level of income that the fisherman earned per month \\
\hline \hline
\end{tabular}

Only the variables that is significant will be adopt in the regression model. After the estimation of WTA, the mean of WTA is calculated. This estimation is derived from the methodology suggested by Cameron (1988). The equation are as follows:

Mean $W T A=\beta \_0+\left(\left(\Sigma \beta \_2 \times \_2, \ldots, \beta \_K X \_K\right)\right) / \beta \_1$

where:

$\beta 0$ indicates the estimated constant; $\beta \mathrm{k}$ is the estimated coefficient of parameters; XK denotes the mean values of explanatory variables; and $\beta 1$ is the estimated coefficient of bidding price. 


\section{RESULTS AND DISCUSSION}

\subsection{Sociodemographic of the Respondents}

From the results, it shows that $97.5 \%$ of male are involved in the fishing activity compared to only $2.5 \%$ of female. The average age for the respondents is 51 years while the mean of the household size is 7 . In average, the respondents had become terubok fisherman for almost 24 years. Majority of the respondents are consisting of Melanau with percentage of $49 \%$ followed by Melayu and Iban with $36.5 \%$ and $12.5 \%$ respectively. Chinese and Lunbawang are the minority with $1.5 \%$ and $0.5 \%$ correspondingly. Most of the respondents had primary education by $45 \%, 28 \%$ of them had no formal education, $28 \%$ had attend secondary school and only $1 \%$ had a diploma. Besides, $48 \%$ of the respondents had earned income range between RM500 to RM 1000 per month while 42\% had earned less than RM 500. Only 10\% of the respondents had earned income more than RM 1000 per month.

The logit model is used to estimate the goodness-of-fit indicated by the coefficient of determination (R2) of 0.232 . This indicates that, about 23 percent of the variation in the dependent variable is explained by the variations in the independent variables.

\subsection{Analysis of Willingness to Accept}

The results of the logit regression model with respect to the willingness to accept (WTA) are presented in table 2 below:

Table 2: Logit Regression Results

\begin{tabular}{lcc}
\hline \hline \multicolumn{1}{c}{ Variable } & Coefficient & p-value \\
\hline Constant & -3.947 & $0.001^{*}$ \\
Bidding & 0.005 & $0.019^{*}$ \\
Melanau & 7.427 & $0.000^{*}$ \\
Malay & 4.125 & $0.009^{*}$ \\
Household & -0.117 & $0.011^{*}$ \\
Fisherman Experience & 0.045 & $0.001^{*}$ \\
Education & -0.291 & 0.215 \\
Income & 0.000 & 0.516 \\
\hline \hline
\end{tabular}

Note: * indicates that the variable is significant at 5 percent level of significance

\subsubsection{Bidding Amount}

The bidding amount refers to the incentives that will be given to the fisherman as a compensation for the environmental loss. In this study, the bidding amount is positively related to the WTA of the fisherman and the variable is statistically significant at 5 percent level of significance. This is because the higher the amount offered as the incentive to the fisherman, the higher the tendency for them to willing to accept the offer. This is supported by the study of Zbinden \& Lee (2005), Pogiola, Arcenas \& Platais (2005) and Fisher (2012). In this study, it shows that when 1 percent increase in the bidding amount, the WTA will increase by 0.5 percent. 


\subsubsection{Race}

The estimation for the race is using dummy variables whereby two majority races are selected which are Melanau and Melayu. The dummy variables are explained by using exponentiated coefficient. Based on the results in Table 2, it shows that both of the major races are statistically significant at 5 percent level of significant and both are positively related. The results indicate that the Melanau were 7.427 times more likely than the other races who is willing to accept the compensation in order to conserve terubok. On top of that, the Malay races were 4.125 times more likely than the other races who is willing to accept the compensation to conserve terubok.

\subsubsection{Household Size}

The previous study by Zbinden \& Lee (2005) had highlighted that the household size is an important determinant that may affect the decision of the fisherman to accept the incentive. In this study it shows that the fishers' household size is negatively related with the amount of WTA. It indicates that when the household size is increasing the amount of WTA will decrease.

\subsubsection{Fisherman's Experience}

The fisherman experience is refering to the number of years that the fishers had become terubok fisherman. Based on the result, it shows that the fisherman experience is positively related to the WTA amount. When 1 percent increase in the fisherman experience, the amount of WTA will eventually increase by 4.5 percent.

\subsubsection{Education}

The education level of the respondents shows a negative relationship towards WTA. This indicates that the fisherman with lower education level does not have enough understanding on the concept of WTA to conserve terubok. Therefore, the education variable is insignificant and cannot be a determinant to influence WTA (Zhibenden \& Lee, 2005).

\subsubsection{Income}

The fishers' monthly income affects the WTA amount positively which is align with the theory. However, the insignificant results on the income that will influence WTA of the fishers may be because the incentive payments are too small compared to the fisherman household average monthly income (Li, Yang, Zhang, Liu \& Zhang, 2018). The fisherman with higher income has a greater management capacity (Zhibenden \& Lee, 2005).

\subsection{Mean of Willingness to Accept (WTA) By the Fisherman}

The mean of WTA is calculated as follows:

$$
\begin{aligned}
\text { VWTA }= & {[(-3.947)-(((7.427 * \text { MELANAU })+(4.125 * \text { MALAY })} \\
& (0.117 * \mathrm{HH})+(0.045 * \text { YEAR })) /((0.005))] \\
= & 301.08
\end{aligned}
$$


Based on the calculation above the mean amount of WTA is RM 301.08. Whereby the total value of WTA for 200 fishermen is RM 60,216. The maximum amount of WTA by the fisherman is RM 822.89 .

\section{CONCLUSION}

The species of Tenualosa toli and Tenualosa macura is an important marine creature to Sarawak as it is a source of income for the nation. Besides, it also provides the livelihood for the fisherman. However, the decreasing number of the tenualosa species is worrying and it is important to conserve them by asking the fisherman on their WTA to conserve terubok. In this study, contingent valuation method (CVM) is used to evaluate the WTA of the terubok fisherman to conserve terubok and logit regression is employed to model the socioeconomic factors that influence the WTA of the fishers.

The results of the logit regression show that the race of the respondents and the fisherman experience have a significant positive effect toward the WTA to conserve terubok while the household size indicates a negative effect but significant to influence the WTA of the terubok fisherman. However, education and income does not show a significant result to influence the WTA.

In order to preserve this population of tenualosa, the sustainable development strategies should be applied to improve this fishery performance in the long run. Looking into the perspective of the terubok fisherman, if the terubok extinct, it will lead to low source of income, hence, it will lead to poverty. As the first sustainable development goals is to end the poverty of the people in the world, an environmentally friendly ways to ways to fish the terubok should be applied. By doing so, the welfare of the fisherman can be protected as well as the fish population can be preserved. Besides, in the study of Mozumder (2019) which related with tenualosa illisha, the author suggests to have an incentive-based program which consist of four main programs under it to protect the population as well as it is the sustainable ways to conserve the population. The main activities under the program is to support the alternative way for the fishers to gain income, the ban period of catching terubok has to be strictly implemented, provide the needs for the fishers along the ban period and also provide an awareness to the community especially the fishers. As for the policy makers side, Goal 17 of the sustainable development can be applied. The respected authorities should strengthen the partnership with the country that have the similar type of tenualosa such as Myanmar and Bangladesh to curb the decreasing number of this population in the water and apply the method that the countries have imposed to save the terubok fish from decreasing.

This study recommends that the fisherman should be more educated for them to realize on the importance of conserving terubok. This is to ensure that this population will not extinct as well as to protect the terubok population for the future generation. The education on the conservation should be emphasized on the younger generation as they are the one who will continue the legacy of the family. Besides, training by using a more sustainable ways of fishing for the youth and inexperienced fishers can be done by the respective authorities as the tools of education for them. On top of that, the incentive amount should be increased in the future study. This is because the fisherman who earn a higher monthly income would have a high tendency to reject a lower compensation amount which is for them it is not worth it. 


\section{REFERENCES}

Anning, A., Egyir, I. S., Kwadzo, G. T. M., \& Kuworm, J. K. M. (2012). Willingness of marine artisanal fishermen to integrate aquaculture in enterprise mix: Evidence from Ghana. Journal of Economics and Sustainable Development, 3(1), 56-67.

Arjunaidi, N. N., Zakaria, M. F., Abdul Aziz, A. H., Shahreza, M. S., Mat Jaafar, T. N. A., Seah, Y. G., \& Nur Asma, A. (2016). Authentication of Tenualosa species in Perak river, Malaysia: Application of morphological measurement and molecular analysis of partial $\mathrm{CO} 1$ and 16S genes to resolve species ambiguity. AACL Bioflux, 9(6), 1355-1363.

Bakeri, N. A., Affizzah, A. M. D., Abdullah, A. M., \& Ashraf, R. (2020). Willingness to Pay to Conserve Tenualosa toli (Terubok). International Journal of Academic Research in Business and Social Sciences, 10(14), 61-69.

Bateman, I. J., Carson, R. T., Day, B., Hanemann, M., Hanley, N., Hett, T., \& Sugden, R. (2002). Economic valuation with stated preference techniques: a manual. Cheltenham, UK: Edward Elgar Publishing Ltd

Bett, R.C., Bett, H.K., Kahi A.K., \& Peters, K.J. (2009). Evaluation and effectiveness of breeding and production services for dairy goat farmers in Kenya. Journal of Ecological Economics, 68, 2451-2460.

Blaber, S. J. M., Milton, D. A., Chenery, S. R., \& Fry, G. (2003). New insights into the life history of Tenualosa ilisha and fishery implications. American Fisheries Society symposium, 35, 223-240.

Blaber, S. J. M., Milton, D. A., Pang, J. L., Vong, O., Ong, B. T., Nyigo, L., \& Lubim, D. (1996). The life history of the tropical shad Tenualosa toil (Valenciennes 1847) from Sarawak: first evidence of protandry in the Clupeiformes. Environmental Biology of Fishes, 46, $225-242$

Brown, T. C. \& Gregory, R. (1999). Why the WTA-WTP disparity matters. Ecological Economy, $28,323-335$.

Cameron, T. A. (1988). A new paradigm for valuing non-market goods using referendum data: maximum likelihood estimation by censored logistic regression. Journal of environmental economics and management, 15(3), 355-379.

Department of Statistics. (2019). Selected Agricultural Indicators, Malaysia, 2019. Retrieved from https://www.dosm.gov.my/v1/index.php?r=column/cthemeByCat\&cat=72\&bul_d=SEU xMEE3VFdBcDJhdUhPZVUxa2pKdz09\&menu_i=Z0VTGU1UHBUT1VJMFlpaXRR R0xpdz09

Fisher, J. (2012). No pay, no care? A case study exploring motivations for participation inpayments for ecosystem services in Uganda. Oryx, 46, 45-54.

Grafton, R. Q., Arnason, R., Bjørndal, T., Campbell, D., Campbell, H. F., Clark, C. W. \& Weninger, Q. (2006). Incentive-based approaches to sustainable fisheries. Canadian Journal of Fisheries and Aquatic Sciences, 63(3), 699-710.

Haneman, W. M. (1991). Willingness to pay and willingness to accept: How much can they differ? American Economics Review, 81, 635-647.

Heal, G. and Schlenker, W. (2008). Sustainable Fisheries. Nature, 455. 1044-1045.

Li, H., Yang, X., Zhang, X., Liu, Y. \& Zhang, K. (2018). Estimation of Rural Households' Willingness to Accept Two PES Programs and Their Service Valuation in the Miyun Reservoir Catchment, China. Sustainability, 10, 170-189.

Mohd, Y. H. J., Chang, S. K. \& Sintoh, M. (1994). Komuniti nelayan: Cabaran, harapan, dan masa depan. Kota Kinabalu: Yayasan Konrad Adenauer. 
Mozumder, M. M. H., Pyhälä, A., Wahab, M., Sarkki, S., Schneider, P., \& Islam, M. M. (2019). Understanding Social-Ecological Challenges of a Small-Scale Hilsa (Tenualosa ilisha) Fishery in Bangladesh. International Journal of Environmental Research and Public Health, 16(23), 4814-4838.

Pagiola, S., Arcenas, A. \& Platais, G. (2005). Can Payments for Environmental Services Help Reduce Poverty? An Exploration of the Issues and the Evidence to Date from Latin America. World Development, 33, 237-253.

Pearce, D. \& Ozdemiroglu, E. (2002) Economic valuation with stated preference techniques, Department for Transport, Local Government and the Regions, Rotherham.

Raduan, M., Sharir, M., \& Aziz, Z. (2007). The Problems of Traditional Fishermen in Peninsular Malaysia: Solutions without an End. Journal of Southeast Asian Studies, 12, 247-258.

Rahim, K. A. A., Tumiran, M. H., Mohd, S., Esa, Y., Ahmad, A., \& Awang, S. (2014). The Status of Tenualosa toli (Valenciennes, 1847) in the South-west Coast of Sarawak, Malaysia. Kuroshio Science, 8(1), 39-44.

Sarawak Inland Fisheries Department. (2015). The differences between three species of Terubok.

Shogren, J. F. \& Hayes, D. J. (1997). Resolving differences in willingness to pay and willingness to accept. The American Economics Review, 84, 255-270.

Zbinden, S., \& Lee, D.R. (2005). Paying for Environmental Services: An Analysis of Participation in Costa Rica’s PSA Program. World Development 33, 255-272. 